\title{
Making Trade Policy in a New Democracy after a Deep Crisis: Indonesia
}

\author{
Kelly Bird ${ }^{1}$, Hal Hill ${ }^{2}$ and Sandy Cuthbertson ${ }^{3}$ \\ ${ }^{1}$ Asian Development Bank, ${ }^{2}$ Australian National University and \\ ${ }^{3}$ Centre for International Economics
}

\section{INTRODUCTION}

建 OW do deep economic crises affect trade policy in developing countries? The conventional historical view is that economies turn inward, in an attempt to protect firms and employment, to restore trade balances, and in response to the perceived negative consequences of globalisation. As a corollary, it is argued that governments find it easier to reform during 'good times', of strong economic growth and low unemployment.

However, over the past two decades, an alternative view has arisen, based on the observed behaviour of countries in crisis. This is what Little et al. (1993) termed the 'new liberalisation'. That is: 'The balance of payments crisis creates the shock environment in which trade liberalization and other radical policy changes become possible' (p. 271). Lal and Myint (1996) developed this argument more generally with their 'crisis hypothesis', that major reforms are often triggered by a significant event: a major economic crisis, a military defeat, the cessation of external support or a natural disaster.

The political economy explanations for this changed behaviour are complex, and include both generic and country-specific factors. The purpose of this paper is to add to our understanding of the nexus between trade policy and crises with reference to a study of the Indonesian experience since the late 1990s. After three decades of mostly rapid economic growth, accompanied by liberalisation in the late 1960s and mid-1980s, the country experienced a deep economic and political

For helpful comments on earlier drafts, the authors would like to thank the Editor and two referees, Dr Mari Pangestu, Dr M. Chatib Basri, and seminar participants at the Australian National University. 
crisis in 1997-98. In 1998, the economy contracted by over 13 per cent, the government signed on to a highly controversial International Monetary Fund (IMF) programme, and the 32-year rule of President Soeharto came to an abrupt end. Authoritarian political structures gave way to a weakened state, a new and fragile democracy and major changes in political and institutional structures.

Our main conclusion is that, perhaps unexpectedly, the Indonesian economy remained largely open over this period. However, in some instances, holding the line on trade reform has had more to do with the personalities involved in trade policy rather than the institutional processes for formulating that policy. Thus, openness is precarious, and not deeply embedded in either supportive institutionalised policy-making structures or widespread popular opinion. Moreover, barriers to domestic trade have risen significantly and now pose a substantial threat to the country's economic integration. This latter issue has received relatively little attention in the literature on trade policy and crises, and yet it may now be the most serious challenge, especially in countries where central government authority is greatly weakened.

We are unaware of a substantial literature on this subject for other developing countries, addressing both international and domestic trade policy. But we conjecture that the Indonesian experience has wide general applicability. This is therefore an issue that other developing countries and international development agencies will need to address in post-crisis environments.

The rest of the paper is organised as follows. Section 2 provides some context on Indonesia, including brief reviews of the evolution of trade policy, the severe economic crisis of 1997-98, and the new post-crisis policy-making framework. Section 3 examines international trade policy since the crisis, while Section 4 investigates the changing domestic trade policy regime. Section 5 provides an analysis of the bureaucracy's ill-fated attempt to develop a new trade policy law in this new political economy environment. Section 6 sums up our arguments and discusses some broader implications.

\section{THE INDONESIAN CONTEXT}

\section{a. Trade Policy under Soeharto}

It is sometimes observed that 'Indonesia was made by God for free trade'. This is a reference to its status as the world's largest archipelagic nation, its porous international borders, 13,000 islands, sometimes rampant smuggling, and proximity to free-trade Singapore and the major international sea lanes of the Malacca Straits. However, the official trade policy pendulum has swung over its six decades as a nation state from virtually complete commercial isolation to very open regimes. 
There have been major changes in Indonesia's trade policy regime since the 1960s. By 1965, the country had disengaged from global trade and investment, and withdrawn from the United Nations, the IMF and the World Bank. The political turbulence of 1965-66 then ushered in a radical shift towards economic orthodoxy, including prompt and effective macroeconomic stabilisation, and an open commercial policy. This period of liberalism was short-lived, however. By the early 1970s, there was a nationalist resurgence. Tariffs were increased, but, more importantly, the government embarked on an ambitious programme of heavy industrialisation underpinned by increased resort to non-tariff barriers (NTBs).

It was only in the early 1980s, and more decisively in the mid-1980s as oil prices continued to fall, that key economic policy-makers - the so-called 'technocrats' - were able to arrest the trend, and then embark on a series of major trade reforms. The second half of the 1980s constituted the high point of the reforms. This was a highly successful case of 'low politics' in the words of Soesastro (1989). The technocratic reformers largely eschewed 'high politics', in the sense of engaging in grand ideological debates. Rather, they developed a strategic reform programme and, partly with the assistance of low-profile foreign advisors, persuaded the president that, in view of the falling international oil prices, the country faced a Mexico/Nigeria scenario (the two most commonly used international comparators) of debt crisis and IMF intervention if the liberalisations were not effected. Once Soeharto was convinced, reform was swift and effective. There was limited public debate.

The most complete set of estimates of the trade policy regime in the late Soeharto regime are those computed by Fane and Condon (1996). Employing a consistent estimation methodology and database, they concluded that the weighted average rate of effective protection for manufacturing (excluding the special case of oil and gas processing) declined from 59 per cent to 16 per cent over the period 1987-95, while the dispersion (standard deviation) fell from 102 to 39 . The coverage of NTBs fell even faster: the percentage of non-oil manufacturing value added affected by NTBs declined from 77 per cent to 17 per cent. ${ }^{1,2}$

Thus, at the time of the crisis, Indonesia was a broadly open economy, and most sectors received quite low protection. By international standards, Indonesia's reforms since 1980 have been incremental rather than 'big bang'. Rajapatirana

\footnotetext{
${ }^{1}$ Various caveats need to be attached to these estimates. They do not take account of the fact that most exporters of manufactures were effectively operating on a free-trade footing through various export zone and duty rebate provisions. Nor are they able to measure the proliferation of cronyrelated and firm-specific protection that began to spread in the 1990s, although such protection was more commonly in non-tradable sectors.

${ }^{2}$ It is surprising, and a commentary on the political economy of trade policy in Indonesia, that these estimates have not been systematically updated for over a decade. This deficiency is in the process of being addressed by Marks (2007); at the time of writing his estimates are incomplete.
} 
(2001) accurately characterises the country as a 'mild reformer' since the 1980s. According to the Sachs-Warner (1995) methodology, Indonesia was 'open' for a few years from the late 1960s and for most of the period since the late 1980s. Moreover, importantly, and borrowing Jagdish Bhagwati's (2002) terminology, the reforms were a case of 'genuine unilateral liberalisation'. They were not part of an IMF/World Bank programme, though these actors played a peripheral role. Nor were they conditional upon reciprocity, although shortly afterwards Indonesia was to enter into several regional trade agreements (RTAs), principally involving the Association of Southeast Asian Nations (ASEAN).

\section{b. The Economic Crisis of 1997-98}

Indonesia experienced a deep economic crisis in 1997-98. Its economic contraction in 1998, of over 13 per cent, was the sharpest among all four crisisaffected East Asian economies. Triggered initially by the run on, and subsequent collapse of, the Thai baht, Indonesia began to experience large-scale capital flight in the third quarter of 1997, resulting in a sharp depreciation of the rupiah and financial distress. ${ }^{3}$ At the peak of the crisis, the dollar exchange rate had fallen from $\mathrm{Rp} 2,500$ to $\mathrm{Rp} 17,500$, and credit in the modern financial sector had effectively dried up. In the first half of 1998, there was a loss of macroeconomic control, and inflation on an annualised basis exceeded 100 per cent.

The economic crisis also precipitated a political crisis, culminating in May 1998 at the end of the 32-year authoritarian Soeharto regime. This created a political and institutional vacuum, heightened social and ethnic tension, and for a period threatened the country's territorial integrity. Investment, both domestic and foreign, also collapsed. In the six years prior to the crisis, net annual foreign direct investment (FDI) inflows averaged $\$ 2.7$ billion, whereas there were net annual outflows of $\$ 1.4$ billion for the five years after the crisis. Since 2004, modest positive net FDI inflows have been recorded.

Reflecting its 'twin crises', both economic and political, Indonesia also recovered more slowly than its East Asian neighbours. Growth was negligible in 1999, but recovered to nearly 5 per cent in 2000 . For the period 2000-06, growth averaged 4.7 per cent, in contrast to the 7.3 per cent recorded in the pre-crisis period 1990 96. In the immediate post-crisis period, exports responded significantly to the exchange rate depreciation, with a lag. However, in spite of buoyant commodity prices in the early years of the twenty-first century, export growth since 1998 has been sluggish, compared to both neighbouring East Asian economies and the country's pre-crisis record (Athukorala, 2006).

\footnotetext{
${ }^{3}$ For detailed analyses of the crisis, see the four-monthly 'Survey of Recent Developments' in the Bulletin of Indonesian Economic Studies. See also Hill (1999).
} 


\section{c. Post-Crisis Institutions and Policy Making}

As a result of the crisis and regime collapse, Indonesia's political environment has changed radically. ${ }^{4}$ There has been a shift from a 'hard', authoritarian, corrupt but growth-oriented state delivering broad-based, rapidly improving living standards, to a 'messy', weakened, democratic, corrupt state, with the political leadership not yet able to provide a clear and unambiguous commitment to growth. The economic policy-making environment has changed, in some cases profoundly, in at least eight key respects. As we shall see below, these changes have major implications for how trade policy is formulated and implemented.

The first is a weakened presidency, a deliberate outcome of the anti-authoritarian sentiment in the wake of the Soeharto regime. Second, there is significantly weaker cabinet unity. Third, the parliament has been transformed from a moribund rubber stamp into a powerful, assertive, legitimate but unpredictable political force. The proliferation of political parties, weak party discipline, the absence of coherent ideologies and policy platforms, and low levels of economic literacy have all resulted in a strong inclination towards populist politics, reflecting a general community reluctance to embrace liberal economic policies.

Fourth, and as a corollary, the newly liberated political parties face the imperative of campaign funding. Inevitably, as we show in the next section, this has spilled over to economic policies as votes are purchased in exchange for the allocation of rents, including in trade policy. Fifth, the long suppressed civil society has suddenly become noisy and influential. Almost invariably, these protests are 'populist' in nature.

Sixth, there has been a marked shift in labour market policies and outcomes from the Soeharto era of low regulation, trade union suppression, but high productivity and wage growth to one of free labour association, but in other respects (rapidly increased minimum wages and restrictive labour regulations) an unfriendly employment environment. In consequence, employment in the modern ('formal') sector has declined, while informal sector employment, typically lower paid and less secure, has been rising (see Manning and Roesad, 2006).

Finally, in an effort to preserve the nation's territorial integrity, a 'big bang' decentralisation reform was hastily passed by the parliament in May 1999, and introduced in January 2001. This involved a significant devolution of power and resources from the central government to the second tier of regional governments.

These changes have far-reaching implications for trade policy. The national government is weakened, and there are many more policy actors. The framework for making economic policy has changed significantly. In particular, the 'low

\footnotetext{
${ }^{4}$ For reviews of post-Soeharto politics and political economy, see Liddle (2005) and Hill and Takashi (2007). 
politics' strategy of the Soeharto era (on which see Soesastro, 1989), that is, one which involves a unified team of economists with a shared policy outlook devising a reform programme and convincing the president of the case for reform, aided by adverse external circumstances and low-profile foreign advisory inputs, is no longer viable. The reformers now have to win over a constituency, in the parliament, the press and civil society, in generally unfavourable ideological circumstances and where money politics plays a larger role. Labour policies have weakened competitiveness in export-oriented sectors, and in the process diluted the constituency in favour of a liberal trade regime. In light of these factors, we now examine trade policy outcomes since the crisis.

\section{TRADE POLICY AFTER THE CRISIS: (1) INTERNATIONAL}

\section{a. An Overview}

As Indonesia became ever more deeply engulfed in the economic crisis of 1997-98, the government signed a series of Letters of Intent (LOIs) with the International Monetary Fund. While most of the conditions in these LOIs pertained to macroeconomic and financial policy, there were a number of trade-related provisions. Several of the trade provisions involved the removal of special privileges granted in highly controversial circumstances to members of the Soeharto family. These included a clove monopoly (governing the marketing and distribution of this key input into the country's kretek cigarette industry) and a so-called national car programme. Monopolies in the cement and forest industries, and in the distribution of several agricultural commodities (oranges, cashew nuts), were substantially dismantled.

\section{b. Aggregate Trends}

Although the government formally exited the IMF programme in late 2004, it also announced its intention to proceed with continuing trade liberalisation, including the tariffication of most remaining NTBs, and a commitment, in principle, to unify tariffs and reduce them to around 5 per cent by 2010 . Thus in 2005 the government began what it called a 'tariff harmonisation' programme with the objective of adopting a uniform tariff rate. Team Tariff, an inter-ministerial team housed in the Ministry of Finance (MOF) was responsible for the programme. It established criteria for setting tariff rates. These included lowering the average tariff rate, and reducing the number of tariff bands. The programme was carried out in two stages. The first stage covered about 1,900 tariff lines, mainly affecting agriculture commodities, and was implemented in early 2005. The second phase, covering more than 9,000 tariff lines, was completed in February 2006. 
The new tariff harmonisation programme specifies a tariff reduction schedule from 2005 to 2020. By 2010, 94 per cent of all tariff lines would have rates at or below 10 per cent. The remaining 6 per cent of tariff lines (the so-called 'sensitive sectors') would have their rates reduced to 10 per cent by 2020 . Team Tariff provided recommendations on the tariff harmonisation programme to the Minister of Finance, who then issued a decree implementing changes to the tariff schedule.

In sum, the tariff harmonisation effort resulted in the following six outcomes. First, a reduction in the weighted average MFN tariff rate from 8.7 per cent in 2004 to a projected 7.7 per cent in 2010 (see Figure 1). Second, an increase in the actual number of tariff bands from eight to nine (the addition is the 8 per cent band). However, by 2010 about 87 per cent of all tariff lines are likely to fall into two bands - the 5 per cent and 10 per cent bands. The tariff harmonisation programme also resulted in fewer tariff lines subject to a zero import duty: the percentage of tariff lines subject to a zero duty falls from 22 per cent in 2004 to 5.5 per cent in 2010 (see Table 1). Third, the dispersion of tariff rates as measured by the standard deviation over the simple mean tariff rate is projected to increase from 2.6 in 2004 to 3.1 by 2010, indicating that the government's initial goal of

FIGURE 1

Weighted Tariff Rates

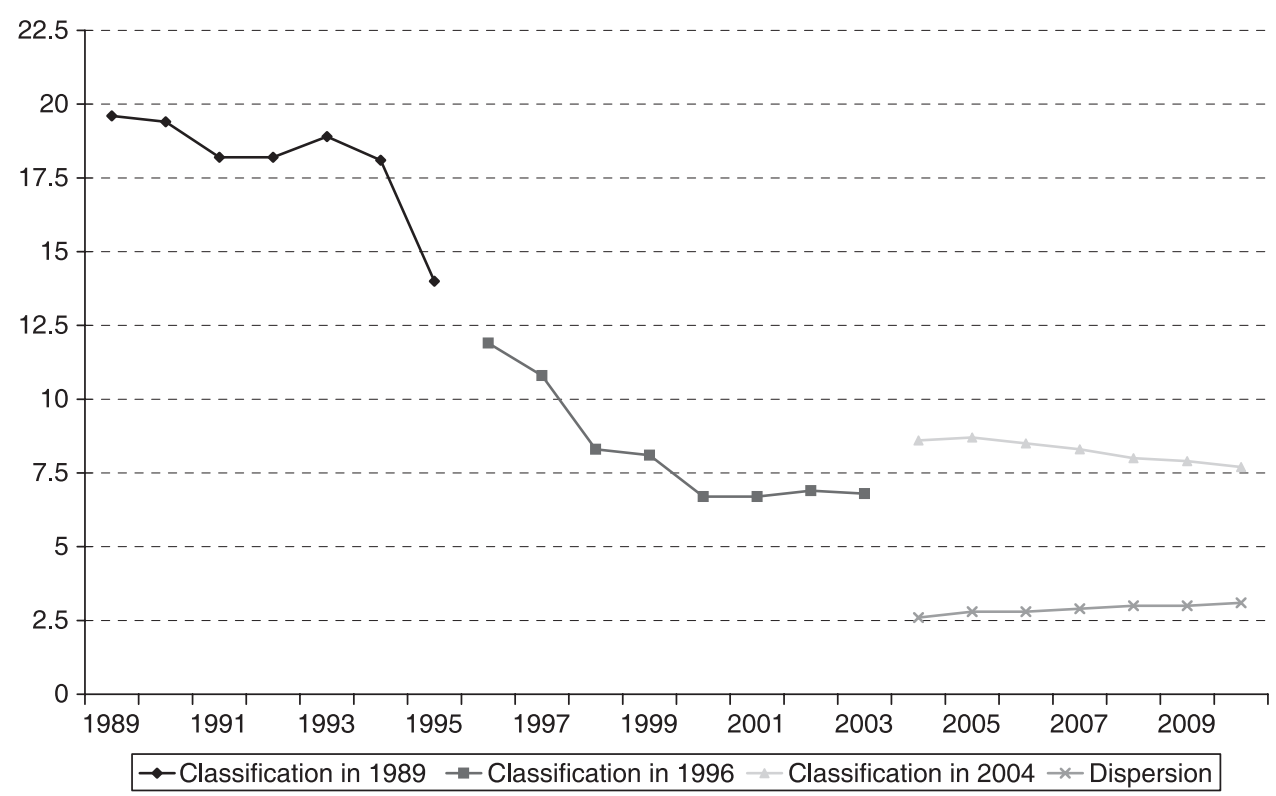

Notes:

Dispersion refers to standard deviation over simple average tariff rate.

Tariff rates are weighted average tariff rates. 
TABLE 1

Distribution of MFN Tariff Rates under the Tariff Harmonisation Programme

\begin{tabular}{llccc}
\hline Tariff Band & 2004 & 2006 & 2008 & 2010 \\
\hline $0 \%$ & $2,334(21.9)$ & $2,454(22.0)$ & $2,320(22.8)$ & $557(5.5)$ \\
$5 \%$ & $4,344(39.0)$ & $4,134(37.1)$ & $3,839(37.2)$ & $6,008(59.0)$ \\
$8 \%$ & - & $74(0.7)$ & $17(0.2)$ & $119(1.2)$ \\
$10 \%$ & $1,709(15.3)$ & $1,703(15.3)$ & $1,663(16.3)$ & $2,835(27.9)$ \\
$13 \%$ & - & $42(0.4)$ & $88(0.9)$ & - \\
$15 \%$ & $1,562(14.0)$ & $1,562(14.0)$ & $1,603(15.7)$ & $163(1.6)$ \\
$20 \%$ & $305(2.7)$ & $590(5.3)$ & $122(1.2)$ & $21(0.2)$ \\
$25 \%$ & $340(3.1)$ & $31(0.3)$ & $44(0.4)$ & $6(0.1)$ \\
$30 \%$ & $11(0.1)$ & $43(0.4)$ & $13(0.1)$ & $14(0.1)$ \\
$35 \%$ & $541(4.9)$ & $523(4.7)$ & $469(4.6)$ & $455(4.5)$ \\
Weighted average tariff rate & $8.6 \%$ & $8.5 \%$ & $8.0 \%$ & $7.7 \%$ \\
Simple average tariff rate & $11.0 \%$ & $10.7 \%$ & $10.3 \%$ & $9.8 \%$ \\
Standard deviation of tariff rates & 28.1 & 29.8 & 30.8 & 30.3 \\
\hline
\end{tabular}

Notes:

Calculated from the official tariff schedule. Figures in parentheses refer to the number of tariff items in each band as a percentage of the total number of items. Data for 2008 and 2010 are officially announced intentions.

Source: Ministry of Finance, Indonesia.

a smaller dispersion in tariff rates will not be achieved. Fourth, an exemption list of products subject to import duty of 35 per cent or more accounts for about 6 per cent of all tariff lines. These products will not be subject to reduced rates until 2020.

Fifth, the sectors are treated differently. The simple average tariff rate for agriculture goods remains relatively high and with only a small decline from 14.9 per cent in 2006 to 14.6 per cent by 2010. Rice is subject to a specific tariff of $\mathrm{Rp} 450 / \mathrm{kg}$ and sugar to Rp750/kg. Rice and sugar are subject to import quotas as well. Non-agricultural goods are subject to a lower average tariff and bigger declines over the schedule period: the simple average falls from 9.2 per cent in 2006 to 8.1 per cent in 2010 .

Finally, the effective tariff rate is much lower than the average MFN tariff rate. For example, customs data suggest that the average, effective tariff rate is in the range of 3-4 per cent (i.e. customs duties divided by import value). This arises for two reasons. One is that Indonesia's commitments to the ASEAN Free Trade Agreement (AFTA) mean that most common effective preferential tariff (CEPT) lines have rates ranging between 0 and 5 per cent. The other is that a substantial proportion of imported intermediate goods are exempt from duty under Indonesia's various export facilitation programmes. ${ }^{5}$

\footnotetext{
${ }^{5}$ Recent data on the value of imported goods exempted from duties are not available, but this could be as much as $\$ 10$ billion per year, or about one-quarter of non-oil and gas imports.
} 
The above analysis refers just to tariff policy. The picture is less clear in the case of non-tariff barriers (NTBs), and this illustrates the precarious nature of Indonesia's trade openness. During the last decade of the Soeharto era, Indonesian trade policy was broadly consistent and unilateralist, both across sectors and with reference to trade policy instruments. In particular, both the average tariff and the number of NTBs declined. However, since 2001, trade policy has become inconsistent. This is indicated by the trends in various trade policy measures.

Measuring NTBs is inherently difficult. By definition, their proponents have an interest in ensuring that they are opaque. In Indonesia, the Ministry of Trade (MOT; until 2004 it was the Ministry of Industry and Trade) generally issues three types of importer licences. An importer-producer (IP) licence means that only the producer of that commodity can also import it. The restricted import licence (or IT) imposes quantitative restrictions on the importation of the commodity. The third type is the importers' registration (NKIP) licence, which requires the importer of a listed commodity to register with the MOT. In principle, this does not involve any restriction on who can register or how much they can import, apart from the inevitable costs of dealing with the bureaucracy. In addition, the MOT occasionally issues inter-island trade registration licences. We give some illustrations of the design of these NTBs in the next sub-section.

Figure 2 provides an estimate of the number of tariff lines (at the nine-digit level) subject to IP or IT restrictions in 2002 and 2004. It is beyond the scope of this paper to quantify their impact. But the overall picture is clear enough: tariff rates under the control of the MOF remained relatively low at a median tariff rate of around 5 per cent. However, import licence requirements, which are under the control of the sectoral ministries and authorised by the MOT, proliferated, their number rising by almost 40 per cent in just two years. This is the crux of Indonesia's trade policy challenge: no minister or agency has control over the full array of trade policy instruments, and is able to adopt an economy-wide public interest viewpoint. The MOF controls tariffs, while sectoral ministries are able to introduce specific NTBs.

\section{c. Case Studies}

Since most NTBs lack transparency, this sub-section provides a brief overview of some recent trade policy measures. They are consistent with what Basri and Soesastro (2005, pp. 10-12) have termed Indonesia's 'creeping protectionism' since 2001. Many of the barriers have been in agriculture, with rice, sugar, wheat flour, soybean and cloves commonly targeted. Anti-dumping has also come to be used as a protectionist instrument.

One example is that in 2001 the MOT established an importer-producer licensing scheme for imports of 26 categories of textile fabric, with the stated objective of preventing smuggling. The scheme appears to have succeeded as official import 
FIGURE 2

Non-Tariff Barriers and Median Tariff Rate

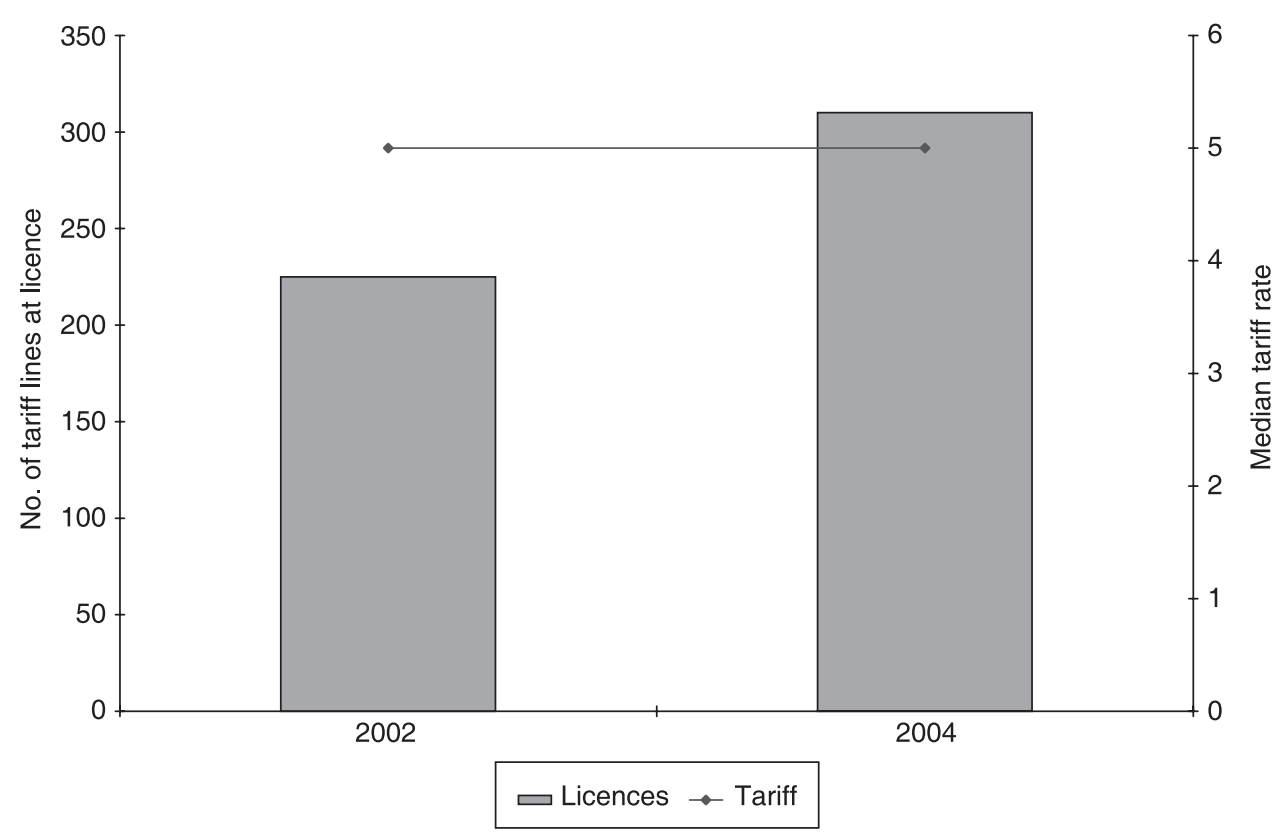

Notes:

NTBs refer to the importer-producer and IT import restrictions at the nine-digit level (about 11,000 tariff lines). The tariff rate refers to the median tariff rate.

statistics recorded a drop in fabric imports between 2001 and 2004. However, these data do not account for imports into bonded zones, where most clothing exporters operate. Export statistics from major foreign suppliers of fabric reflect these unrecorded imports.

Furthermore, in 2003 the MOT introduced importer's registration licences for selected commodities. More than 500 tariff lines at the nine-digit level were subject to this scheme. Again, its stated purpose was to clamp down on alleged smuggling. While the importer's registration licence is generally merely a nuisance, and does not restrict the importation of a commodity, there are cases where the registration licence has been used in a restrictive manner. For example, the MOT refused to register importers of cloves, effectively creating a ban on imports. No rigorous assessment of the effectiveness of NKIP licences, or whether the various import licence schemes are in the 'public interest', was undertaken.

Other non-tariff restrictions include a ban on farmed shrimp imports, imposed in 2004 following allegations of the trans-shipment of shrimps of Chinese origin. The ban was extended in June 2006. Sugar imports were also restricted by an MOT decree issued in 2002 stipulating that licensed importers, defined as just five state entities, were permitted to import sugar. This replaced the estimated 
800 private importers in operation before the decree was issued. This licence was accompanied by a specific tariff per kilogram, of Rp550/kg for cane and Rp700/kg for industrial grade and white refined sugar. The ad valorem tariff equivalent of these specific tariffs varies with the prevailing international prices of cane and refined sugar, but was estimated to be 30 per cent and 35 per cent, respectively. The decree in effect created a cartel as the importers with licences accounted for over 90 per cent of white sugar produced on Java and over 60 per cent in the country as a whole. ${ }^{6}$

Wheat flour has also been a subject of policy dispute. In 1998, the industry was deregulated as part of the IMF programme. The monopoly of the National Food Logistics Agency (BULOG) over the importation of wheat flour and the distribution of flour within the domestic market was removed, and the import tariff rate set at zero. The dominant producer, PT Bogasari, was then subject to unrestricted import competition for the first time. Subsequently, its market share fell from around 90 per cent in 1998 to 65 per cent by 2001. In 2001 the company requested the Indonesia Safeguards Committee, located in the MOT, to impose a tariff of 20 per cent on imports, on the grounds that the surge in imports was damaging the wheat flour industry and could potentially cause job losses. The Safeguards Committee ruled in favour of Bogasari, and the MOT signed an approval letter to raise the tariff to 20 per cent. The MOF refused to implement the decision. An eventual compromise between the two resulted in an increase in the import tariff rate to 6 per cent. Not satisfied with the outcome, the MOT used its regulatory authority to introduce an NTB in the form of a standards regulation for wheat flour imports, as well as establishing one laboratory to test wheat flour at the major seaport, Jakarta. Importers of wheat flour would have to wait for certification from the laboratory that the imported flour met the specified standards. This measure reportedly resulted in delays in releasing consignments from the port. It also increased uncertainty for importers, as standards were not clearly defined.

\section{d. Explanations and Qualifications}

This conclusion, that the trade regime remained broadly open, requires both explanation and qualification. First, why has Indonesia remained broadly open over this period, in spite of the many pressures to erect substantial barriers to trade? The deep crisis reinforced suspicion of the global economy, and triggered calls for 'temporary' protection for displaced workers and ailing firms. ${ }^{7}$ This was

\footnotetext{
${ }^{6}$ For details of these estimates and discussion of the institutional arrangements and protectionist measures in the industry, see Stapleton (2006).

${ }^{7}$ And as noted above, the resort to labour market populism, itself a political consequence of the crisis, increased unemployment and exacerbated the adverse effects of the crisis.
} 
especially the case since the IMF intervention was highly unpopular, and was seen in many quarters as a 'Washington' orchestrated programme of interference. Underpinning this opposition was a general mistrust of market forces and liberalism, born out of the country's anti-colonial struggle. An additional factor, noted above, was that the advent of democracy introduced an imperative to raise campaign funding, and with it the pressure to buy votes through trade protection. These developments also occurred against a backdrop of the international trade policy architecture drifting away from a firm embrace of multilateralism and towards a set of 'hub-and-spoke' preferential trading arrangements. Domestic opponents of trade liberalisation were able to exploit these trends for their own purposes.

The political economy factors explaining why these pressures for protection have essentially been resisted, at least so far, are complex and inter-related, but the following are central to the analysis. ${ }^{8}$ One was that, in the immediate post-crisis period, and for all its unpopularity, the IMF LOI played a role in at least checking protectionist pressures. Moreover, some of the blatantly political protection that was dismantled was popular domestically and well received. A second factor was the very large depreciation of the rupiah in 1997-98, which provided some exchange rate protection for tradables. Related to this, economic recovery in the immediate post-crisis period was crucially dependent on the growth of the export sector, which was thereby politically empowered, and of course opposed to protection.

A third explanation is that finance ministries are typically central to the resolution of a crisis, and these now more powerful agencies are generally more likely to favour lower protection. In Indonesia, this ministry had been the key driving force for trade liberalisation in the 1980s. Most ministers since then have been economists with a commitment to reform. Thus the resistance to protectionist pressures has been as much to do with personalities as institutions. Fourth, and related, this liberalisation was still a recent memory at the time of the crisis, it had built up a constituency of support and thus any unwinding of successful reforms was likely to be resisted.

Fifth, notwithstanding the faltering WTO negotiations, the global trend towards liberalisation at this time had strong intellectual appeal, particularly with the example of the increasingly open Asian giants, China and India. Finally, at the margin, Indonesia was a signatory to various regional trade agreements AFTA, in particular - which provided a mild barrier to increased protectionism.

Thus the reformers were broadly able to nullify the incipient protectionist pressures. But, as noted, this achievement has been precarious, is not deeply

\footnotetext{
${ }^{8}$ See Basri and Hill (2004), Basri and Soesastro (2005) and Basri and Patunru (2007) for discussion of this issue.
} 
embedded in the Indonesia polity, and is subject to frequent attempts to secure exemptions. Six recent developments illustrate this proposition.

First, the economic efficiency effects of the harmonisation programme are not clear, as the dispersion of tariff rates will slightly increase by 2010. Moreover, the programme still exhibits a cascading tariff structure, which would be consistent with a positive average effective rate of protection for final goods. ${ }^{9}$

Second, there has been a pronounced swing from protection of manufactures to agriculture. Most of the NTBs granted since 2000 have been in agriculture. Four factors appear to explain this trend, in Indonesia and elsewhere. One is that most of the past intellectual reform endeavour has focused on manufacturing, which was the most heavily protected sector. Consequently, with a few exceptions, manufacturing protection in Indonesia is quite low, and firms have adjusted their operations to this low protection environment. The spread of globally integrated international production networks in East Asia, which are predicated upon the unhindered movement of goods across international boundaries, has reinforced this trend. Another predisposing factor has been that, with democracy, rural votes matter, and politicians are able to exploit this factor along by appealing to sentimental notions of food self-sufficiency. In addition, it is now easier to introduce protection for agriculture than manufactures owing to various loopholes (quarantine, etc.) and to the fact that the OECD North has been extremely slow to liberalise its own agricultural protection. Finally, Indonesia's Department of Agriculture has been traditionally protectionist, and this predisposition has further increased after the appointment of the new Minister for Agriculture in 2004. ${ }^{10}$

Third, the reformers have also had limited success in managing trade facilitation measures. That is, liberalisation is a necessary but not sufficient condition for successful internationally-oriented growth. In particular, there are at least three key prerequisites for countries to participate in the growth of these multinational enterprise (MNE)-dominated global production networks (see Athukorala, 2006): high-quality logistics infrastructure, speedy import-export procedures and an open FDI environment. In all three respects, the Indonesian environment is deficient. The country's infrastructure investment (as a proportion of GDP) is about half the East Asian average. Export-import procedures have also slowed significantly, and are now among the longest in East Asia. ${ }^{11}$ Indonesia's foreign

\footnotetext{
${ }^{9}$ The programme aims to set tariffs in 2010 at 5 per cent for raw materials, between 5 and 10 per cent for intermediate inputs, and 10 per cent for final goods.

${ }^{10}$ The Minister is a senior member of the Justice and Prosperity Party, a small Islamist party and member of the ruling government coalition. The party's economic platform tends to be more inward-looking than the other parties in the coalition.

${ }^{11}$ At a general level, these bureaucratic complexities are illustrated by the 2007 World Bank Doing Business Survey, which ranks Indonesia 135th out of 175 countries in terms of ease of doing business.
} 
investment regime is less inviting than most of its East Asian competitors, and for several years after the crisis FDI flows were negative. ${ }^{12}$

Fourth, Indonesia's disappointing export performance since the crisis, notwithstanding the sharp exchange rate depreciation in 1997-98, has triggered pressure for a range of second-best 'stopgap' measures. One is the growing popularity of export zones, which offer simpler administrative procedures and (sometimes) freer trade. Additional investment incentives have also been foreshadowed. The proliferation of these zones reflects the inability of policy makers to achieve further first-best, economy-wide liberalisation.

Fifth, there has also been increased resort to preferential trade arrangements. Until very recently, Indonesia was multilateralist in its approach to trade negotiations (Basri and Soesastro, 2005). The principal exception has been the special case of the ASEAN Free Trade Agreement (AFTA), in recognition of overriding geostrategic considerations. In any case, however, AFTA's discriminatory effects have been mild, since its rules of origin provisions are less restrictive than most preferential agreements, and most of its concessions have been multilateralised. However, commencing in 2003, Indonesia embarked on negotiations towards its first bilateral trade agreement, with Japan. Inevitably, most sensitive trade issues have been exempted from the agreement. Several additional bilateral agreements are under discussion.

Sixth, the Indonesian government is yet to develop institutional mechanisms to deal with the analytics of trade policy issues. While Team Tariff has established basic guidelines for the committee members to follow when determining tariff reductions, in practice its final recommendations are essentially achieved through negotiations between the different line ministries. No standard analytical tools are employed. For example, there are no simulated effective rates of protection to ascertain the potential impact on resource allocation. The negotiations are believed to have resulted in slowing tariff reform in so-called 'sensitive sectors'.

\section{TRADE POLICY AFTER THE CRISIS: (2) DOMESTIC}

Discussions of trade policy focus primarily on barriers at the international boundary. Yet Krugman's (1991) fusion of the trade and geography literatures reminds us of the importance of national economic integration and the range of natural and policy barriers to it. There is a large literature on domestic infrastructure issues in developing countries, and the resultant 'incomplete markets'. But there

${ }^{12}$ Although these flows, based on balance of payments estimates, do under-estimate the extent of the MNE presence, especially that via takeovers and locally-funded acquisitions. See Takii and Ramstetter (2005). 
is much less discussion of policy barriers to national integration, especially in the context of spatially diverse, weak states in which the centre is unable to impose nationally consistent commercial policies in the wake of deep economic and political crises. This may be compounded post-crisis by related reforms which are deliberately intended to weaken the centre through a systematic programme of decentralisation, as has occurred in Indonesia, the Philippines, Russia and elsewhere.

The implications for patterns of trade are potentially far-reaching. In the case of a huge archipelagic state such as Indonesia, for example, some regions especially those proximate to the highly open neighbouring economies of Singapore and Malaysia - could become more integrated with the global economy than with other Indonesian regions.

The regulatory environment for domestic trade in Indonesia is extensive, ill-defined and complex. A wide array of domestic trade and trade-related laws are currently in existence in Indonesia, and they provide the basis for government policies and practices in this field. These include the following: BRO, licensing law (1932), Law on goods (1961), Law on trade in goods in special areas (1962), Law on warehouses (1965), Law on measurement (1981), Registration law (1982), Law on commodity futures (1997), Law on consumer protection (1997), and the Law concerning the prohibition of monopolistic practices and unfair business competition (1999).

The first of these dates back to the colonial era and is in the Dutch language. Three date from the socialist 'Guided Economy' period of the early 1960s, and reflect the priorities of that era, namely centralised authority, together with a state-dominated, closed economy. Much of their focus was to clamp down on 'speculation', 'smuggling' and other attempts to evade a highly distorted economy experiencing hyperinflation by the mid-1960s. Another two were introduced in the immediate aftermath of the 1997-98 economic crisis, and aimed at addressing public concerns with monopolistic practices and consumer protection.

Indonesia's Constitution and its amendments contain little reference to domestic trade issues. However, the following broad principles appear to be widely accepted, if not actively enforced. First, that there should be free internal movement of goods, services and labour. The strongest statement is contained in the 1999 Laws on decentralisation, to the effect that local/regional regulations cannot be inconsistent with national policy, or harm public welfare. Second, as a corollary, Indonesia should be regarded as a single national customs zone, in which international trade policy is the sole prerogative of the national government, and sub-national tiers of government cannot interfere with the flow of goods and services across international boundaries. Third, there is general agreement that public-interest principles be enshrined in all legislation and regulations, although practice lags considerably behind this principle. Fourth, as an increasingly decentralised but formally unitary state, with all three major tiers of government 
having some responsibility for economic policy and the business environment, there is supposed to be a clear demarcation of powers and responsibilities among governments.

Indonesia is a unitary state, and for the first 50 years of Independence, power was increasingly centralised in Jakarta and in the office of the President. It then suddenly embarked on a 'big bang' decentralisation programme. ${ }^{13}$ President Habibie introduced, and the parliament quickly passed, Laws 22/1999 and 25/1999. The former provides the basis for political and administrative decentralisation, while the latter is concerned with fiscal arrangements. The new system became operational on 1 January 2001, 18 months after the laws had been passed. Authority was devolved to the second tier of local government, the kabupaten and municipalities, thus largely by-passing the provinces. At the same time, the number of second-level governments has risen sharply, from a little over 250 during most of the Soeharto era, to approximately 450 . This was a decentralisation motivated at a time of widespread inter-communal and ethnic violence by a fear of territorial disintegration, and occurring when the central government was at its weakest. Owing to the scale and rapidity of change, centre-region relations are in transition, and are regularly being modified by new laws and regulations. ${ }^{14}$

Nevertheless, there has been a proliferation of regional charges and taxes issued by local governments, many affecting inter-regional commerce. Some of these regulations have a legal basis, in the sense that they are based on laws passed by properly constituted local authorities. Others are short-term, opportunistic, illegal exactions, in which members of the military and police feature prominently. Some very approximate indication of the incidence and magnitude of these regional taxes and charges can be obtained from two sources. The first is records maintained by central government agencies that are responsible for the monitoring and examination of these regional regulations. The second is based on various surveys and anecdotal information concerning the incidence of quasi-legal charges, especially related to goods in transit.

On the officially monitored regulations, according to unpublished MOF data ${ }^{15}$ over the period 2001 to January 2006 provinces issued 570 regulations relating to taxes and charges and kabupaten/kota 12,950 regulations, a total of 13,520 issued by the two tiers. Of this total, 71 per cent $(9,573)$ of the regulations had been formally received by the Ministry (all regulations are supposed to be

\footnotetext{
${ }^{13}$ See Rasyid (2004) and Brodjonegoro (2004) for details of these changes, and an early evaluation of their impacts.

${ }^{14}$ These include Law 32/2004, which replaced the original decentralisation Law 22/1999, and which specifies that local government decrees cannot conflict with those issued by the central government, and Law 34/2006, which sets out the taxes and charges that may be levied by local governments.

${ }^{15}$ As reported in a document 'Monitoring Peraturan Daerah: Pajak Daerah, Retribusi Daerah' ('Monitoring Regional Regulations: Regional Taxes, Regional Charges').
} 
immediately sent to the central government). Of those received, 61 per cent $(5,794)$ had been examined. And of these, 11 per cent (611) had been recommended to be abolished (475) or revised (136). There is no indication as to whether the regional authorities responded to these recommendations. ${ }^{16}$

A number of field surveys provide additional information. Lewis (2003) investigated the incidence of regional regulations in 2001, the first year of operation under decentralisation. He concluded that most of the 1,000 levies were imposed unilaterally, and with very limited central government supervision and monitoring. Simanjuntak and Lewis (2005) observed that, beginning in 2001, regional governments have issued at least 1,000 regulations each year, with the central government recommending cancellation or revision of about 100 per year. The largest number of cancellations/revisions has occurred in the agriculture and livestock sector. Consistent with the observations above, the most frequent complaint in business and consumer surveys was that the regional governments had not provided a clear justification for the levies. The authors also note that there is considerable regional variation in business licensing procedures, with regard to the payments involved and the complexity of regulatory compliance.

Since there are no widely collected statistics on the incidence of illegal levies, various field surveys are the main source of information. They indicate a widespread incidence. For example, Simatupang (2005) cites the case of an eight-ton consignment of oranges from Karo (North Sumatra) to Jakarta having to pay levies totalling Rp190,000 at 45 collection points. These levies were equivalent to Rp24/kg, in addition to much time lost and inconvenience. A recent unpublished World Bank survey in Aceh found that goods in transit encountered barriers at each kabupaten boundary; in some cases they were also at kecamatan boundaries. Most of the barriers were erected by the police and army. One consignment that was systematically monitored observed 12 checkpoints on a cross-province trip in Aceh (northern Sumatra), and estimated that the levies were equivalent to 11 per cent of the value of the goods. ${ }^{17}$

Notwithstanding the data limitations, several observations on these growing domestic trade barriers are warranted. The first is the complexity and magnitude of the monitoring and examination tasks. Not only do central government officials have to obtain copies of thousands of (frequently incomplete or unclear) regulations, but they also have to examine them against the existing body of rapidly evolving law and regulations across several departments and jurisdictions. Many of the barriers are in any case not reported, especially those involving the

\footnotetext{
${ }^{16}$ The Ministry of Home Affairs undertakes a similar monitoring activity, with less complete data but broadly similar results.

${ }^{17}$ See also Montgomery et al. (2002) for detailed field reports on the incidence of inter-regional trade barriers.
} 
military and police. Second, the array of taxes and levies is extremely wide. They include practically every imaginable impost, from the common trade taxes to the employment of workers from outside the local area. There are also great inter-regional variations in their incidence. Third, there are numerous cases of ambiguity, where it is not clear whether a levy is justifiable. A frequent example concerns road levies: in principle, these may reflect user-pays principles, in effect a toll road. But they are more commonly regarded as an easy opportunity to impose transit levies.

\section{THE OFFICIAL RESPONSE: A DRAFT TRADE LAW}

In 2001, the Ministry of Trade commenced work on a new trade law. This was in response to various factors: complaints over domestic trade barriers, the introduction of the decentralisation programme, some new laws introduced in the wake of the 1997-98 economic crisis that had implications for trade policy, and increased general pressure on the bureaucracy in the wake of the sudden swing from authoritarian to democratic rule. This was a well-intentioned though illfated attempt at making trade policy, and it is useful to briefly review the exercise for the lessons learnt on making trade policy in such an environment.

The proposed bill was initially intended to guarantee the free movement of goods and services within the national market. However, the resulting draft law simply bundled together modern laws with old trade laws without reforming them. In this sense, the draft trade bill reflected the weaknesses of trade policy formulation in Indonesia, and of how the bureaucracy was not entirely 'brought' into the economic reforms of the 1980s and 1990s. While the initial objective may have been to set rules to counter the proliferation of local government trade regulations, the MOT expanded the draft to include foreign and domestic trade, with the intention of 'modernising' the body of trade laws. Eventually the Ministry found this to be too difficult, and so it opted for an 'umbrella' law on trade, in an attempt to reform and consolidate the existing body of law into one, as well as adding new laws.

In principle, economic legislation is introduced for a number of reasons. These include, for example, the modernisation of the existing body of law to reflect contemporary challenges and issues; addressing a significant market or government failure; and addressing equity concerns in the community. However, the 'umbrella' approach of this draft did not appear to accomplish any of these purposes in a substantial way. The draft law did explicitly repeal three old laws/ regulations. But it selected key provisions from these repealed laws and wrote them into the new draft law. Consequently the draft law bundled modern laws with several outdated economic laws. Many of the latter were introduced at a time when there was extensive state control over the economy, proliferation of 
licensing, import controls and extensive price controls. Most of these laws are no longer relevant in an open, modern economy. ${ }^{18}$

The draft law was also overly prescriptive in content. It prescribed both practices that are and are not permissible, rather than simply prescribing practices deemed illegal, as is generally the approach in modern codes. ${ }^{19}$ Consequently, the draft law signalled a continuation of a 'bureaucratic control' mentality, which is pervasive in many old economic and social laws in Indonesia. Recent international trends in legislative drafting have shifted from an overly prescriptive approach to a more descriptive one, whereby laws focus on processes and guidelines.

Some provisions in the draft law signalled potential 'backtracking' on previous reforms, and are perhaps indicative of the fact that the drafting team in the MOT had not really embraced the reforms over the past two decades. One example was a proposed provision that foreign-owned producers must distribute their products through an intermediary. Apparently this was inserted without wide consultation with stakeholders and in any case these restrictions were removed in 1998 as part of measures to improve efficiency in the distribution system.

There were at least three broad areas not dealt with in the draft law. First, there was very little mention of processes for making trade policy, including guidelines, tests for policy makers (that is, the public interest) to follow when setting policy, and rules on transparency (for example, electronic publication of regulations and impact statements). Second, the draft law adopted a sectoral approach to trade policy. For example, it assumed that the MOT sets tariff policy. However, good trade policy requires a 'whole of government' approach that takes an economywide perspective on trade policy. A third gap in the draft law is that it was silent on clarifying the respective roles of, and relationships between, the national and sub-national governments in the area of trade policy. For example, there could have been an explicit provision stating that sub-national governments could not introduce regulations affecting imports and exports.

The drafting of the bill was also indicative of the policy formulation processes that worked well under the Soeharto regime, but are less relevant and effective under a newly emerging democracy. The drafters did not consult widely with stakeholders. There were no public hearings and submissions were not requested. Nor did the MOT carry out or solicit rigorous analytical work prior to drafting the law. As it happened, the parliament, independent of the Ministry's efforts, was also drafting a similar law on domestic trade, primarily to restrict foreign investment in the retail sector as a means of protecting traditional retailers. Moreover, little attempt was made to draw on international experience and lessons.

\footnotetext{
${ }^{18}$ For example, the Law on warehouses (1962) regulates inventory of so-called 'important' or 'basic' necessities so as to enforce the price controls and control the hyperinflation of the period (early 1960s). ${ }^{19}$ For example, one provision stated that foreign-owned businesses must distribute their goods through an intermediary.
} 
In the event, in spite of a large bureaucratic commitment within the MOT over several years, the draft trade law was never made public and was never formally submitted to the parliament. It is beyond the scope of this paper to discuss the reasons for this. Essentially both the Minister and senior bureaucrats regarded it as impractical. But the key point to emphasise is that, while Indonesia remains a largely open economy, there is still a strong bureaucratic propensity for intervention.

\section{CONCLUSIONS}

Several points emerge from this examination of Indonesian trade policy since the economic and political crisis of 1997-98 and the transition from authoritarian to democratic government. These conclusions are grounded in the Indonesian experience, but they are also of general relevance for other developing countries in similar circumstances.

First, Indonesia has remained a largely open economy, notwithstanding a deep economic crisis and a highly unpopular IMF programme. This may appear surprising, but there is a plausible political economy explanation for why there has been no significant retreat into protectionism.

Second, however, this openness is precarious and not deeply embedded in either institutions or public opinion. Moreover, owing to major changes in Indonesia's political architecture since the crisis, the earlier basis for reforms, of 'low politics' in which technocrats convinced the president of the case for change, is unlikely to sustain the future reform agenda. In addition, the international commercial policy architecture cannot be relied upon to be supportive of continuing unilateral reform.

Third, trade reform is about much more than barriers to commerce at international boundaries. Perhaps unexpectedly, this is where major problems have arisen in Indonesia after the crisis. That is, a weakened central government has been able to maintain broadly open international boundaries, but it has been powerless to prevent the proliferation of a range of quasi-legal and blatantly extortionist exactions on domestic trade. Combined with a far-reaching decentralisation programme and under-investment in infrastructure - both common features of post-crisis countries - Indonesia risks fragmenting into a series of poorly connected regional economies, some of which may be more integrated with neighbouring states than with the rest of the country.

Fourth, as in many other developing countries, Indonesian trade policy making broadly occurs in an institutional vacuum. The ad hoc inter-departmental Team Tariff sets tariffs on an informal basis, without reference to clear objectives and rigorous analytical research, and in a largely non-transparent manner. It has no control over other trade measures, principally NTBs, and, as noted, the more protectionist line ministries seek to by-pass the Team. Such a policy-making 
structure worked well in the 1980s when the technocrats were in control, the main game was to persuade the president, and the strategy of Soesastro's (1989) 'low politics' guided policy reform. But it is much less well suited to an era of assertive legislatures and noisy civil society, where vocal elements of both are predisposed to protectionism, and where a constituency has to be won over by argument.

To maintain the reform momentum in Indonesia, and elsewhere, and ensure that past achievements are not overturned, there would appear to be at least four requirements. One is that, to the extent possible, a 'cordon sanitaire' be established around key areas of economic policy. This process is already under way in Indonesia, with the establishment of an independent central bank, legislated rules governing fiscal deficits and public debt, and (as a second-best option for economy-wide reforms) the establishment of export zones in which firms operate on a free-trade footing and in a less complicated regulatory environment.

Another requirement is that, in a newly democratic era, the case for reform has to be advanced and won in the public domain. This requires a major change in the role and activities of the Indonesian economics profession. No longer do the debates have to be won only in the presidential office or around the cabinet table. Members of parliament have to be convinced, as does the general public.

Third, these two approaches will be more effective if there are institutionalised means of establishing high-quality yet accessible analytical capacity guiding public policy. This may include, for example, the establishment of an independent agency which reports on the benefits and costs of any measure intended to provide assistance to a particular industry or firm. Ideally, this process would involve public hearings in which the proponents of such assistance - whether from the private sector or the bureaucracy - would be expected to make their case in public, and to have it scrutinised by independent technical staff.

Finally, trade policy reform 'works' when it delivers results and thereby wins over a constituency for further reform. This, in turn, requires competent macroeconomic management (to ensure that the real exchange rate does not overshoot); institutions such as a customs service which ensure the speedy and unhindered movement of goods across international borders; an open and uncomplicated foreign investment regime which connects Indonesian firms and workers to global production and distribution networks; and labour markets which translate economic growth into growing employment opportunities. Since the crisis, Indonesian economic policy has been just adequate with respect to the first variable, weak on the second, ambivalent on the third, and deficient on the fourth.

\section{REFERENCES}

Athukorala, P.-C. (2006), 'Post-Crisis Export Performance: The Indonesian Experience in Regional Perspective', Bulletin of Indonesian Economic Studies, 42, 2, 177-211. 
Basri, M. C. and H. Hill (2004), 'Ideas, Interests and Oil Prices: The Political Economy of Trade Reform during Soeharto's Indonesia', The World Economy, 27, 5, 633-56.

Basri, M. C. and A. A. Patunru (2007), 'How to Keep Trade Policy Open: The Case of Indonesia', unpublished paper, University of Indonesia, Jakarta.

Basri, M. C. and H. Soesastro (2005), 'The Political Economy of Trade Policy in Indonesia', ASEAN Economic Bulletin, 22, 1, 3-18.

Bhagwati, J. (2002), 'Introduction: The Unilateral Freeing of Trade versus Reciprocity', in J. Bhagwati (ed.), Going Alone: The Case for Relaxed Reciprocity in Freeing Trade (Cambridge, MA: MIT Press), 1-30.

Brodjonegoro, B. (2004), 'The Effects of Decentralization on Business in Indonesia', in M. C. Basri and P. van der Eng (eds.), Business in Indonesia: New Challenges, Old Problems (Singapore: Institute of Southeast Asian Studies), 125-40.

Fane, G. and T. Condon (1996), 'Trade Reform in Indonesia, 1987-1995', Bulletin of Indonesian Economic Studies, 32, 3, 33-54.

Hill, H. (1999), The Indonesian Economy in Crisis: Causes, Consequences, and Lessons (Singapore: Institute of Southeast Asian Studies).

Hill, H. and S. Takashi (2007), 'The Indonesian Economy: A Decade after the Crisis', Asian Economic Policy Review, 2, 127-45.

Krugman, P. (1991), Geography and Trade (Cambridge, MA: MIT Press).

Lal, D. and H. Myint (1996), The Political Economy of Poverty, Equity and Growth (Oxford: Oxford University Press).

Lewis, B. (2003), 'Tax and Charge Creation by Regional Governments under Fiscal Decentralization: Estimates and Explanations', Bulletin of Indonesian Economic Studies, 39, 2, 177-92.

Liddle, R. W. (2005), Year One of the Yudhoyono-Kalla Diumvirate', Bulletin of Indonesian Economic Studies, 41, 3, 325-40.

Little, I. M. D., R. N. Cooper, W. M. Corden and S. Rajapatirana (1993), Boom, Crisis, and Adjustment: The Macroeconomic Experience of Developing Countries (New York: Oxford University Press for the World Bank).

Manning, C. and K. Roesad (2006), 'Survey of Recent Developments', Bulletin of Indonesian Economic Studies, 42, 2, 143-70.

Marks, S. (2007), 'Effective Rates of Protection: Methodology and Preliminary Calculations for Indonesia', unpublished paper, Ponoma College, Claremont.

Montgomery, R., S. Sumarto, S. Mawardi, S. Usman, N. Toyamah, V. Febriany and J. Strain (2002), 'Deregulation of Indonesia's Interregional Agricultural Trade', Bulletin of Indonesian Economic Studies, 38, 1, 93-117.

Rajapatirana, S. (2001), 'Developing-Countries' Trade Policies in the 1990s: Back to the Future', in D. Lal and R. Snape (eds.), Trade, Development and Political Economy: Essays in Honour of Anne O. Krueger (London: Palgrave), 78-95.

Rasyid, M. R. (2004), 'The Policy of Decentralization in Indonesia', in J. Alm, J. MartinezVasquez and S. M. Indrawati (eds.), Reforming Intergovernmental Fiscal Relations and the Rebuilding of Indonesia (Cheltenham: Edward Elgar), 65-74.

Sachs, J. and A. Warner (1995), 'Economic Reform and the Process of Global Integration', Brookings Papers on Economic Activity, 1, 1, 1-118.

Simanjuntak, R. and B. Lewis (2005), 'Rural Investment Climate and Regional Taxes and Licensing Procedures', unpublished paper, World Bank, Jakarta, August.

Simatupang, P. (2005), 'Agricultural Marketing and Competition', unpublished paper, World Bank, Jakarta, October.

Soesastro, M. H. (1989), 'The Political Economy of Deregulation in Indonesia', Asian Survey, 29, 9, 853-69.

Stapleton, T. (2006), 'Institutional Determinants of Indonesia's Sugar Trade Policy', Bulletin of Indonesian Economic Studies, 42, 1, 95-104.

Takii, S. and E. D. Ramstetter (2005), 'Multinational Presence and Labour Productivity Differentials in Indonesian Manufacturing, 1975-2001', Bulletin of Indonesian Economic Studies, 41, $2,221-42$. 